\title{
Efektivitas Media Pembelajaran Gadumasa Untuk Meningkatkan Hasil Belajar Siswa Sekolah Dasar
}

\section{Dwi Prasetya $^{1 *}$, Henny Dewi Koeswanti ${ }^{1}$}

${ }^{1}$ Prodi Pendidikan Guru Sekolah Dasar, Universitas Kristen Satya Wacana,

Salatiga, Indonesia,

*e-mail: prasetya.d20@gmail.com

\begin{abstract}
Abstrak
Smartphone saat ini sudah merambah ke berbagai kalangan termasuk anak-anak, namun pemanfaatannya tidak banyak ke pembelajaran mengingat konten pembelajaran yang dirancang sesuai kurikulum yang berlalu masih sangat sedikit. Dampaknya adalah siswa memanfaatkan smartphone untuk bermain game online atau menonton video hingga lupa waktu. Pola seperti telah mempengaruhi aktivitas belajar siswa di sekolah sehingga berdampak kurang baik terhadap hasil belajar siswa. Penelitian ini bertujuan untuk mengembangkan media pembelajaran Gadumasa (Game Edukasi Maze Berbasis Android) yang valid dan efektif dalam meningkatkan hasil belajar. Penelitian ini merupakan jenis penelitian dan pengembangan. Model pengembangan yang digunakan adalah model ASSURE. Hasil pengujian menunjukkan bahwa validitas Gadumasa menurut ahli materi, ahli media, dan ahli desain pembelajaran menunjukkan kategori tinggi. Skor yang diperoleh masing-masing ahli secara berurutan yaitu; $80 \%$, $76 \%$, dan $74 \%$ sehingga dinyatakan bahwa media pembelajaran Gadumasa valid dari aspek isi, media, dan desain pembelajaran. Uji efektivitas dilakukan melalui pra eksperimen pada satu kelas. Rerata hasil pretest adalah $36,36 \%$ sedangkan rerata posttest yakni $81,81 \%$. Dengan demikian ada perbedaan rerata yang signifikan sehingga media Gadumasa dinyatakan efektif meningkatkan hasil belajar tema 6 siswa kelas IV SD.
\end{abstract}

Kata kunci: game, media pembelajaran, hasil belajar

\begin{abstract}
Smartphones have now penetrated various groups including children, but their use is not much to learning considering that there are still very few learning contents designed according to the passing curriculum. The impact is that students use smartphones to play online games or watch videos until they lose track of time. Such a pattern has affected student learning activities at school so that it harms student learning outcomes. This study aims to develop a valid and effective Gadumasa (Android-based Maze Educational Game) learning media in improving learning outcomes. This research is a type of research and development. The development model used is the ASSURE model. The test results show that the validity of Gadumasa according to material experts, media experts, and learning design experts shows a high category. The scores obtained by each expert are sequential, namely; $80 \%, 76 \%$, and $74 \%$ so it is stated that the Gadumasa learning media is valid from the aspects of content, media, and learning design. The effectiveness test was carried out through pre-experimentation in one class. The mean pretest result was $36.36 \%$ while the posttest means was $81.81 \%$. Thus, there is a significant difference in the mean so that the Gadumasa media is declared effective in improving the learning outcomes of the theme 6 of grade IV elementary school.
\end{abstract}

Keywords: android, learning media, learning outcomes

\section{Pendahuluan}

Kompetensi abad 21 merupakan kompetensi utama dan wajib yang harus dimiliki sumber daya manusia agar mampu bertahan hidup seiring tuntutan perkembangan teknologi informasi yang pesat. Kompetensi abad 21 yaitu memiliki daya pemikir yang mampu ikut membantu tatanan sosial ekonomi serta sadar pengetahuan tentang perkembangan teknologi yang selalu berubah secara dinamis. Pemanfaatan teknologi informasi memberikan pengaruh yang besar pula dalam bidang pendidikan. Pesatnya 
produk-produk teknologi baru yang dimanfaatkan dalam bidang pendidikan juga merupakan upaya mewujudkan pembelajaran modern dalam rangka menjawab tuntutan kebutuhan abad 21.

Salah satu upaya pengembangan kompetensi abad 21 khususnya di kalangan siswa adalah dengan menerapkan pembelajaran berpusat pada siswa. Pembelajaran yang berpusat pada siswa memberikan kesempatan kepada siswa untuk mengembangkan potensi yang mereka miliki menjadi kemampuan yang semakin lama semakin meningkat, tidak hanya dari aspek kognitif saja tetapi juga dari aspek sikap dan keterampilan (Rusman, 2017). Pembelajaran yang berpusat pada student center memberikan kebebasan pula bagi guru dalam merancang dan mengemas pembelajaran menjadi lebih kreatif dan inovatif. Penerapan pembelajaran yang berpusat pada siswa dapat dilengkapi dengan penggunaan media pembelajaran yang tepat dan ideal. Media pembelajaran dapat menyalurkan komunikasi antara guru dan siswa menjadi lebih efektif dan efisien (Mawardi, 2014).

Media pembelajaran yang melibatkan kegiatan bermain tentunya akan menciptakan suasana belajar yang menyenangkan. Bermain dalam konteks belajar perlu memanfaatkan media pembelajaran yang menarik, bervariatif, sesuai dengan karakter siswa, memanfaatkan teknologi informasi, serta tren smartphone yang berkembang pada zaman ini. Pada era modern ini, trend yang sedang berkembang sangat pesat di Indonesia adalah Smartphone Android. Penggunaan Smartphone tidak dapat dilepaskan dari aktivitas-aktivitas di berbagai kalangan baik anak-anak, remaja, dan orang dewasa saat ini sudah biasa dengan smartphone. Khusus tentang penggunaan smartphone di kalangan anak-anak selama ini didominasi dengan aktivitas menonton video dan bermain game online. Penggunaan untuk edukasi masih sangat minim. Apabila anak-anak kecanduan dengan game online dapat menurunkan motivasi belajar dan menyebabkan kesulitan konsentrasi dalam mengikuti pembelajaran (Nisrinafatin, 2020; Sundara et al., 2020).

Sejalan dengan pendidikan dan perkembangan tren masa kini, guru dituntut untuk memanfaatkan dan menggunakan teknologi secara optimal sebagai media dalam menyampaikan informasi kepada siswa. Salah satu bentuk teknologi yang dapat dimanfaatkan sebagai media pembelajaran yaitu teknologi game yang dapat diinstal di smartphone yang memiliki sistem operasi android (Azhar, 2011). Keunggulan penggunaan smartphone dalam pembelajaran telah ditunjukkan oleh beberapa hasil penelitian. Pembelajaran yang menggunakan smartphone memiliki nilai rata-rata yang lebih baik dari kelas yang tidak menggunakan smartphone, media pembelajaran berbasis android memberikan dampak positif bagi siswa, dan siswa lebih mudah memahami materi (Novianto et al., 2015; Prayudi et al., 2015).

Berdasarkan pernyataan-pernyataan di atas, akan dikembangkan suatu produk media pembelajaran "Gadumasa" berbasis Android untuk meningkatkan hasil belajar siswa. Dalam pengembangan media ini, hanya difokuskan pada materi kelas IV Tema 6 Subtema 1. Pengembangan media pembelajaran ini menawarkan beberapa kelebihan, antara lain game ini dikemas dalam bentuk sebuah permainan yang dapat dipasang di Smartphone Android menjadi lebih praktis dalam memainkannya, sehingga secara mandiri anak dapat memainkannya kapan saja dan dimana saja. Bentuk game ini berupa suatu maze atau labirin yang nantinya siswa akan mencari jalan keluar dari beberapa jalur yang ada. Ketika memainkannya siswa akan menemukan soal-soal yang harus dijawab agar dapat menyelesaikan permainan dengan baik. Untuk itu tujuan penelitian ini adalah menguji validitas dan efektivitas media pembelajaran Gadumasa dalam meningkatkan hasil belajar siswa kelas IV sekolah Dasar.

\section{Metode}

Penelitian ini menggunakan jenis penelitian dan pengembangan atau Research and Development (R\&D). Penelitian pengembangan merupakan penelitian yang dilakukan untuk menyempurnakan produk yang telah ada atau menghasilkan produk baru yang dapat dipertanggungjawabkan (Sukmadinata, 2016). Langkah pengembangan produk 
menggunakan model pengembangan ASSURE yang terdiri dari enam langkah: Analisis Learner, State Objective, Select Media \& Materials, Utilize media \& Materials, Require Learner, \& Evaluasi \& Revise (Smaldino et al., 2008). Penelitian dilakukan kepada siswa kelas 4 di SD Negeri 1 Selodoko Kecamatan Ampel, Kabupaten Boyolali. Data dikumpulkan melalui wawancara, observasi, angket analisis karakteristik siswa, angket ahli atau pakar, dan tes. Wawancara dan observasi dilakukan kepada guru kelas untuk mengetahui permasalahan dalam lingkungan sekolah dan pembelajaran di kelas. Angket analisis karakteristik siswa digunakan untuk mengetahui permasalahan dan potensi yang dapat dikembangkan. Angket digunakan untuk menguji validitas Gardumasa. Tes berupa pretest dan posttest digunakan untuk mengukur efektivitas Gardumasa dalam meningkatan hasil belajar siswa. Data hasil uji evaluasi oleh ahli sebagai validasi produk selanjutnya dianalisis menggunakan rating scale. Analisis awal data skor yang diperoleh dari ahli dijumlahkan dan dirata-rata, skor tersebut dihitung dengan menggunakan rumus:

$$
A P=\frac{\text { Skor_Aktual }}{\text { Skor_Ideal }} \times 100 \%
$$

Keterangan:

AP = Angka Persentase

Skor Aktual = Skor yang diberikan oleh validator ahli

Skor Ideal = Skor maksimal hasil kali antara jumlah item dengan skor maksimal masingmasing item.

Angka persentase tersebut selanjutnya dikelompokkan menjadi lima kategori sebagaimana tersaji pada Tabel 1.

Tabel 1. Skala Kategori uji validitas

\begin{tabular}{ll}
\hline Interval & Kategori \\
\hline $81-100 \%$ & Sangat tinggi \\
$61-80 \%$ & Tinggi \\
$41-60 \%$ & Cukup \\
$21-40 \%$ & Rendah \\
$1-20 \%$ & Sangat rendah \\
\hline
\end{tabular}

Berdasarkan interval interpretasi pada tabel 1, maka media pembelajaran Gadumasa dapat dikatakan layak/ Valid untuk dicobakan apabila persentase minimal mencapai kategori tinggi yaitu $\geq 61 \%$. Data uji efektifitas media pembelajaran diperoleh dari hasil pretest dan posttest, nilai yang diperoleh kemudian dianalisis menggunakan kriteria persentase ketuntasan klasikal. Media pembelajaran Gadumasa dikatakan efektif untuk meningkatkan hasil belajar apabila kriteria hasil ketuntasan berada pada interval $76 \%-100 \%=$ Tuntas (Aqib, 2011).

\section{Hasil dan Pembahasan}

Hasil dari studi pendahuluan melalui studi literatur menghasilkan kajian kurikulum 2013 khususnya di tingkat Sekolah Dasar dan menentukan materi yang akan didistribusikan ke dalam media. Adapun hasil yang ditemui dan dijadikan dasar yakni materi kelas IV Tema 6 dengan muatan pelajaran Bahasa Indonesia, IPA, dan IPS. Selain itu, kajian dalam pengembangan media juga dilakukan dengan mengumpulkan data-data serta informasi tentang tahapan-tahapan dalam mengembangkan media, software yang diperlukan dalam mengembangkan media yakni: Construct 2 dan Corel Draw X7. Software tersebut dipilih karena mudah dalam menggunakan dan tidak memerlukan script coding yang rumit, lalu tool-tool lain yang dibutuhkan serta data-data pendukung lainnya. 
Selain studi kepustakaan pada studi pendahuluan juga dilakukan studi lapangan terhadap guru kelas dan siswa kelas IV. Hasil dari observasi dan wawancara ditemukan bahwa selama ini guru belum mengoptimalkan media pembelajaran yang inovatif dan mengikuti perkembangan teknologi. Guru hanya menggunakan media pembelajaran peninggalan dari kelas ke kelas yang sudah sejak lama digunakan tanpa ada pembaruan. Sehingga pembelajaran menjadi kurang menarik motivasi belajar siswa. Pada awal pembelajaran siswa memperhatikan namun lama-lama siswa merasa bosan dan sering izin keluar kelas dengan alasan ingin cuci tangan, dll.

Pada tahap pengembangan media pembelajaran Gadumasa dikembangkan menggunakan model ASSURE. Langkah pertama, model pengembangan ASSURE adalah analisis karakteristik siswa. Data karakteristik siswa dapat diketahui melalui kuesioner yang telah disebar kepada 19 siswa kelas IV sebagai responden. Hasil dari data ini akan digunakan sebagai acuan awal dalam pengembangan media pembelajaran yang tepat sesuai karakteristik siswa kelas IV Sekolah Dasar. Aspek pertama yang diukur adalah karakteristik gaya belajar siswa yang dapat dilihat pada Tabel 2 berikut.

Tabel 2. Hasil Analisis Karakteristik Gaya Belajar Visual Siswa

\begin{tabular}{ccccc}
\hline \multirow{2}{*}{ Kompetensi } & \multicolumn{4}{c}{ Jumlah } \\
\cline { 2 - 5 } & Tidak & Ragu & Ya & \\
\hline Gaya belajar visual siswa & 2 & 11 & 6 & 19 \\
\hline
\end{tabular}

Berdasarkan tabel 2 di atas, dapat dilihat bahwa siswa yang memiliki gaya belajar visual sebanyak 6 siswa dengan persentase sebesar $31,5 \%$ sedangkan 2 siswa menunjukkan tidak memiliki gaya belajar visual dengan persentase 10,7\%. Dengan demikian, dapat disimpulkan bahwa ada potensi dasar untuk mengembangkan media pembelajaran GADUMASA sesuai dengan karakteristik siswa yang memiliki gaya belajar visual. Aspek lain dari karakteristik siswa yang diukur yaitu kemampuan awal siswa dalam memahami materi tema 6 subtema 1 dan kemampuan awal siswa dalam mengoperasikan HP/ Smartphone/ Mobile Phone yang dapat dilihat pada Tabel 3 berikut.

Tabel 3. Hasil Analisis Karakteristik Kemampuan Awal Siswa

\begin{tabular}{llcccc}
\hline \multirow{2}{*}{ No. Kompetensi } & \multicolumn{3}{c}{ Jumlah } & \multirow{2}{*}{ Total } \\
\cline { 2 - 5 } & Kemampuan materi tema 6 & 1 & 12 & 6 & 19 \\
\hline 1. & subtema 1 & 0 & 1 & 18 & 19 \\
\hline 2. & Kemampuan pengoperasian HP & Kurang Baik & Baik & \\
\hline
\end{tabular}

Berdasarkan data pada tabel 3, dapat dilihat bahwa sebagian besar siswa memiliki pemahaman terkait tema 6 subtema 1 yaitu "Cita-citaku" yang cukup rendah. Hasil tersebut diperoleh dari 12 dari 19 siswa dengan persentase $63,1 \%$ kurang baik dalam pemahaman tema 6 . Hanya 6 siswa yang menunjukkan bahwa siswa mampu memahami materi dengan baik dengan persentase 31,5\%. Data berbanding terbalik ditunjukkan pada aspek kemampuan awal siswa mengoperasikan HP/ Smartphone/ Mobile Phone. Sebanyak 19 siswa dengan persentase 94,7\% sudah mampu mengoperasikan $H P /$ Smartphone/ Mobile Phone dengan baik.

Selain itu, dari kegiatan wawancara dan observasi yang dilakukan kepada guru kelas dan siswa. Kebanyakan siswa tidak merasa bosan karena materi yang disampaikan banyak teks hafalan. Pembelajaran juga masih terpaku dengan buku dan belum menggunakan media yang memanfaatkan perkembangan teknologi sehingga dapat menarik perhatian siswa. Dengan demikian, media pembelajaran Gadumasa yang akan dikembangkan harus memanfaatkan perkembangan teknologi dan menyenangkan bagi siswa sehingga dapat menarik perhatian dan termotivasi untuk belajar. Selain itu siswa yang termotivasi dalam pembelajaran akan berdampak dalam peningkatan hasil belajar. 
Langkah kedua yaitu merumuskan tujuan pembelajaran. Merumuskan tujuan pembelajaran didapat dari penurunan Kompetensi Dasar dan Indikator yang dapat dilihat dari pemetaan Permendikbud No. 37 Tahun 2018 tentang Standar Isi dan standar proses. Pemetaan KD dan Indikator dapat dilihat pada Tabel 4 berikut.

Tabel 4. Pemetaan KD \& Indikator

\section{Kompetensi Dasar BAHASA INDONESIA \\ 3.6 Menggali isi dan amanat puisi yang disajikan secara lisan dan tulis dengan tujuan kesenangan.}

\section{IPA}

3.2. Membandingkan siklus hidup beberapa jenis makhluk hidup serta mengaitkan dengan upaya pelestariannya.

\section{Indikator Pencapaian Kompetensi}

3.6.1 Mengenal jenis-jenis profesi beserta tugas utamanya.

3.6.2 Menyebutkan ciri-ciri- Puisi dengan tema cita-cita.

3.6.3 Menentukan amanat puisi bertemakan profesi/cita-cita secara lisan.

2.1 Menggali informasi siklus hidup hewan yang tidak mengalami metamorfosis

2.2 Menggali informasi siklus hidup hewan yang mengalami metamorfosis.

2.3 Menggali informasi siklus hidup hewan yang mengalami metamorfosis sempurna beserta contohnya.

2.4 Menggali informasi siklus hidup hewan yang mengalami metamorfosis tidak sempurna beserta contohnya.

4.2 Membuat skema siklus hidup beberapa jenis makhluk hidup yang ada di lingkungan

2.1 Membuat skema siklus hidup belalang sekitarnya, dan slogan upaya IPS pelestariannya.

3.1 Mengidentifikasi karakteristik 1 ruang dan pemanfaatan sumber daya alam untuk kesejahteraan masyarakat tingkat kota/kabupaten sampai tingkat provinsi.

Langkah yang dilakukan selanjutnya adalah merumuskan tujuan pembelajaran berdasarkan Kompetensi Dasar (KD) dan Indikator yang telah dirumuskan pada Tabel 4. Tujuan pembelajaran tema 6 subtema 1 dirumuskan sebagai berikut: (1) Melalui akses aplikasi Gadumasa peserta didik dapat Mengidentifikasi minimal 3 cita-cita/profesi serta kegiatan utamanya sehari-hari seperti guru, dokter, pilot dll dengan tepat. (2) Melalui akses aplikasi Gadumasa peserta didik dapat Mengidentifikasi minimal 3 hal- hal yang penting pada puisi seperti baris, bait, rima, serta isi dengan benar. (3) Melalui akses aplikasi Gadumasa peserta didik dapat Membuat 1 puisi dari media elektronik atau cetak dengan kreatif. (4) Melalui akses aplikasi Gadumasa peserta didik dapat Mengidentifikasi minimal 2 perbedaan siklus hidup hewan yang mengalami metamorfosis dengan tepat. (5) Melalui akses aplikasi Gadumasa peserta didik dapat Mengidentifikasi minimal 2 perbedaan siklus hidup hewan yang mengalami metamorfosis dengan tepat. (6) Melalui akses aplikasi Gadumasa peserta didik dapat mengetahui minimal 2 contoh siklus hidup hewan yang mengalami metamorfosis sempurna dengan tepat. (7) Melalui akses aplikasi Gadumasa peserta didik dapat mengetahui minimal 2 contoh siklus hidup hewan yang mengalami metamorfosis tidak sempurna dengan tepat. (8) Melalui akses aplikasi 
Gadumasa peserta didik dapat Menyelesaikan 4 tahapan siklus hidup hewan belalang dengan tepat. (9) Melalui akses aplikasi Gadumasa peserta didik dapat Menyelesaikan 5 tahapan siklus hidup hewan kupu-kupu dengan tepat. (10) Melalui akses aplikasi Gadumasa peserta didik dapat Mengidentifikasi minimal 3 bentuk perbedaan lingkungan serta hubunganya dengan profesi dengan tepat.

Langkah ketiga yaitu memilih strategi, media, dan materi yang akan digunakan. Pada tahap ini, pemilihan dilakukan mempertimbangkan data-data yang diperoleh sebelumnya sehingga saling berkesinambungan. Strategi yang dipilih yaitu menggunakan pendekatan saintifik sesuai karakteristik Kurikulum 2013, model pembelajaran yang dipilih adalah modifikasi dari games-based learning dengan Problem Based Learning, dengan metode pembelajaran ceramah, tanya jawab, diskusi, dan penugasan. Sedangkan media pembelajaran yang dipilih adalah media berbasis aplikasi game dengan memanfaatkan teknologi berupa perangkat keras Smartphone. Materi yang dipilih adalah kelas IV Tema 6 subtema 1 yang terdiri dari muatan pelajaran Bahasa Indonesia tentang Puisi, IPA tentang siklus hidup hewan, dan IPS tentang karakteristik lingkungan dan pemanfaatannya. Pengembangan media pembelajaran Gadumasa dapat dilihat pada gambar 1 dan gambar 2.

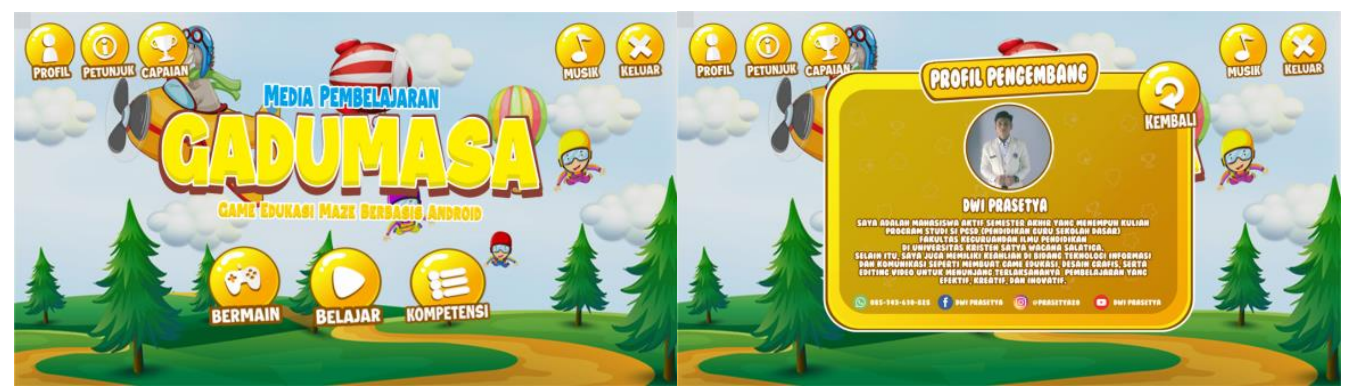

Gambar 1. (a) Hasil pengembangan halaman depan; (b) Profil pengembang.

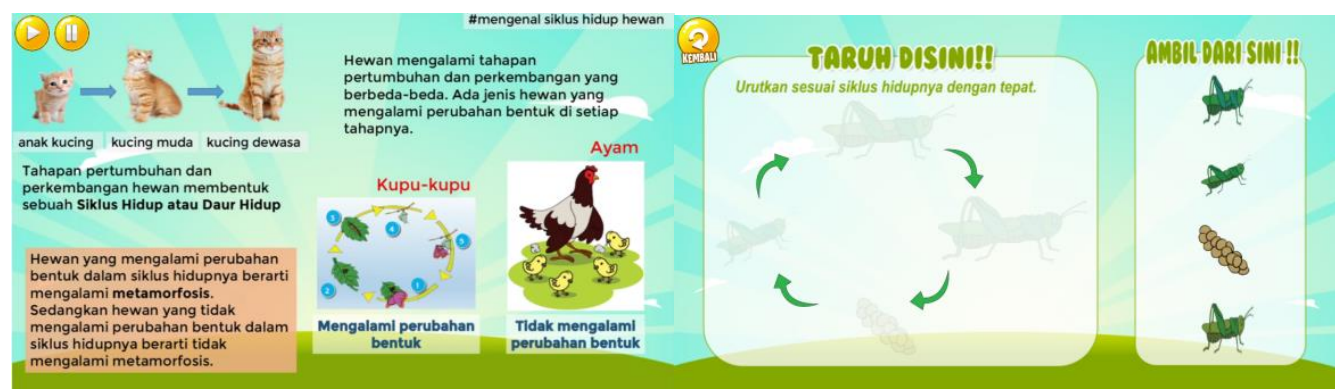

Gambar 2. (a) Materi dalam bentuk video pembelajaran; (b) Materi dalam bentuk unjuk kerja

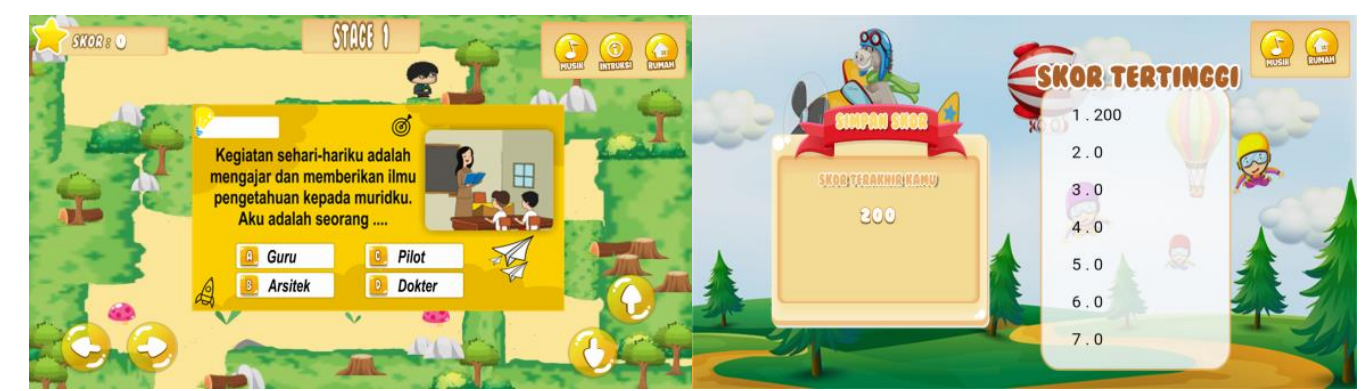

Gambar 3. (a) Hasil pengembangan uji kompetensi; (b) Leaderboard skor tertinggi

Langkah keempat yaitu memanfaatkan teknologi, media, dan materi yang telah disusun pada langkah-langkah sebelumnya. Pada langkah ini berarti produk media pembelajaran GADUMASA yang telah selesai dikembangkan akan digunakan dalam 
pembelajaran kelas. Adapun kegiatan yang perlu dilakukan sebelum produk dapat digunakan didalam pembelajaran kelas yaitu menyiapkan alat dan bahan yang dibutuhkan termasuk didalamnya Rencana Pelaksanaan pembelajaran (RPP), Lembar Kerja Peserta Didik (LKPD), Media Gadumasa, dan bahan pendukung lainnya. Namun sebelum media pembelajaran Gadumasa digunakan dalam pembelajaran di kelas, media sudah terlebih dahulu melalui beberapa uji ahli/ pakar antara lain uji ahli materi, uji ahli media, dan uji ahli desain pembelajaran. Hasil uji ahli/ pakar dapat dilihat pada tabel 5 berikut.

Tabel 5. Hasil Analisis Validasi Uji Ahli/Pakar

\begin{tabular}{llllll}
\hline No & Aspek & Skor Ideal & Skor Aktual & Presentase & Kategori \\
\hline 1. & Materi Pembelajaran & 50 & 37 & $74 \%$ & Tinggi \\
2. & Media Pembelajaran & 75 & 57 & $76 \%$ & Tinggi \\
3. & $\begin{array}{l}\text { Desain } \\
\text { Pembelajaran }\end{array}$ & 60 & 48 & $80 \%$ & Tinggi \\
\hline
\end{tabular}

Berdasarkan hasil analisis validasi yang dilakukan kepada ahli pakar materi, media dan desain pembelajaran menunjukkan kategori Tinggi. Persentase ahli pakar materi, media, dan desain pembelajaran secara berurutan yaitu $74 \%, 76 \%$, dan $80 \%$. Persentase tersebut masuk dalam kategori Valid dengan catatan revisi sesuai masukan ahli. Hasil uji tersebut juga menunjukkan kategori layak untuk digunakan dalam pembelajaran di kelas karena menunjukkan persentase $\geq 61 \%$. (Lihat Tabel 1 ).

Tahap perbaikan dan evaluasi dilaksanakan setelah mendapat umpan balik dari pada ahli melalui angket validasi yang diberikan. Setelah mendapat umpan balik maka akan diperbaiki hingga menjadi produk media pembelajaran Gadumasa yang sempurna. Hasil perbaikan berdasarkan masukan dan saran dari masing-masing ahli dapat dilihat pada tabel 6 berikut.

Tabel 6. Revisi sesuai saran ahli

\section{Saran}

Terdapat beberapa gambar yang terlalu kecil terutama jika aplikasi digunakan di smartphone, sehingga tidak terlihat

Pada materi dalam video lebih baik lagi jika diberi tombol kembali atau ke halaman depan.
Materi pembelajaran audio yang digunakan kurang jelas di awal (suara terlalu pelan)
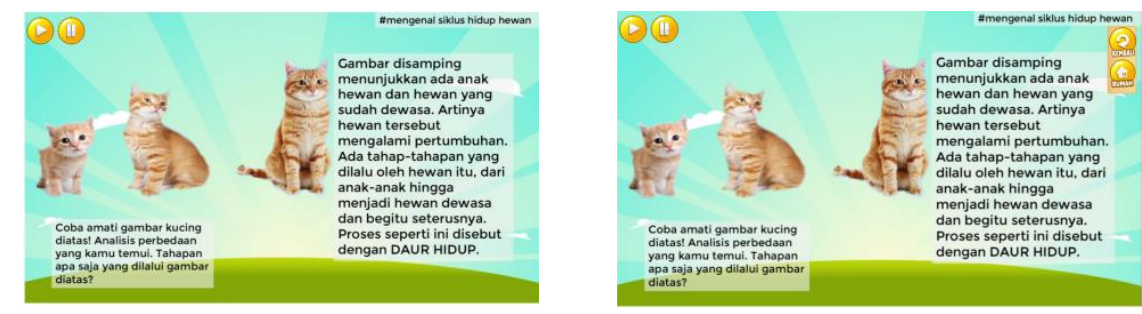

Dilakukan perbaikan dengan mengedit audio melalui software adobe audition cs 2015, baru kemudian dilakukan perbaikan media di software Construct 2 pada produk. 
Sedangkan evaluasi dilakukan pada setiap tahapan dari analisis peserta didik sampai dengan tahap akhir revisi. Dari data yang didapat menunjukkan hasil bahwa media pembelajaran Gadumasa untuk meningkatkan hasil belajar tema 6 siswa kelas IV SD dapat digunakan dan menarik dalam pembelajaran.

Tahap pengujian dilaksanakan pada saat uji coba terbatas. Tahap ini dilaksanakan untuk memperoleh seberapa tinggi tingkat efektifitas media pembelajaran GADUMASA dalam meningkatkan hasil belajar tema 6 siswa kelas IV SD. Hasil dari tingkat keefektifan media pembelajaran Gadumasa dilihat dari hasil pretest dan posttest pada tabel 7 berikut:

Tabel 7. Data Hasil Pretest dan Posttest Berdasarkan Skor Persentase Ketuntasan

\begin{tabular}{ccc}
\hline Kegiatan & Nilai rata-rata & Ketuntasan \\
\hline pretest & 64,09 & $36,36 \%$ \\
posttest & 81,81 & $81,81 \%$ \\
\hline
\end{tabular}

Dari hasil posttest diatas diketahui bahwa ketuntasan klasikal siswa keseluruhan hasilnya melebihi $75 \%$ yaitu dengan persentase $81,81 \%$ dari seluruh jumlah siswa (11 siswa). sehingga media pembelajaran Gadumasa dikatakan efektif digunakan dalam pembelajaran tema 6 subtema 1 di kelas IV SD.

Proses desain dan pengembangan produk media pembelajaran Gadumasa dilakukan dengan menggunakan model pengembangan ASSURE. Hasil yang diperoleh dari pakar materi pembelajaran diperoleh persentase sebesar $80 \%$ dengan kategori tinggi. Pencapaian ini tidak terlepas dari pengembangan materi berdasarkan kurikulum yang berlaku, pengembangan materi sesuai karakteristik sekolah, dan penjabaran materi secara konkret sehingga mudah dipahami.

Validitas dari aspek media diperoleh presentase $76 \%$, dari hasil tersebut, media pembelajaran termasuk dalam kategori Tinggi. Unsur media gambar dan teks memiliki peran penting dalam media Gadumasa. Gambar-gambar yang digunakan sangat menarik, mendukung kejelasan materi, dan sesuai dengan karakteristik siswa. Validitas dari aspek desain pembelajaran diperoleh persentase $74 \%$ dengan kategori Tinggi. Pada aspek desain difokuskan pada petunjuk belajar dan strategi pembelajaran melalui game. Petunjuk Gadumasa sangat memberikan kemudahan kepada siswa. Petunjuk yang jelas akan memudahkan siswa mengeoperasikan media (Rozie, 2018). Strategi game menggunakan prinsip segmentasi yaitu materi disajikan dalam format kecil dan apabila ia tuntas mempelajari materi tersebut siswa dapat melanjutkan ke materi berikutnya. Penerapan prinsip ini dapat memudahkan siswa mengintegrasikan pengetahuan (Ibrahim et al., 2012).

Uji efektivitas menunjukkan bahwa media Gadumasa efektif meningkatkan hasil belajar siswa. Hal ini terjadi karena media Gadumasa mampu memberikan tantangan kepada siswa dalam menyelesaikan setiap tahapan atau level game. Setiap level memiliki tingkat kesulitan yang berbeda-beda. Semakin rendah level game maka tingkat kesulitannya juga rendah. Jika siswa dapat menyelesaikan soal-soal pada level 1 maka ia dapat melanjutkan ke level 2. Penerapan game dalam pembelajaran memiliki peluang untuk meningkatkan pembelajaran (Sandrone \& Carlson, 2021). Sambil bermain siswa secara tidak langsung sudah belajar materi pelajaran. Media Gadumasa mampu memberikan rasa sedang kepada siswa. Rasa senang bagi anak sekolah dasar sangatlah penting. Jika ia merasa senang maka akan banyak imajinasi siswa yang berkembang. Game pada media Gadumasa memberikan suasana yang menyenangkan kepada siswa karena pembelajaran dikemas dalam situasi permainan. Rasa senang yang ditimbulkan memberikan efek positif terhadap motivasi siswa sehingga berdampak terhadap peningkatan outcome pembelajaran (Awan et al., 2019; Perini et al., 2018).

\section{Simpulan}

Pengembangan media pembelajaran Gadumasa telah valid dan efektif meningkatkan hasil belajar khususnya pada tema 6 pada siswa kelas IV Sekolah Dasar. Media Gadumasa dikembangkan menggunakan model ASSURE dan dirancang sesuai 
analisis yang telah dilakukan. Berdasarkan hasil validasi dari para ahli bahwa media pembelajaran Gadumasa dikatakan valid dari aspek materi, media, dan desain pembelajaran dan ketiga aspek tersebut dicapai dalam kategori tinggi. Efektivitas media Gadumasa dalam meningkatkan hasil belajar siswa karena media yang dikembangkan mampu memberikan suasana tantangan dan mampu menghadirkan suasana senang kepada siswa sehingga motivasi belajar siswa meningkat dan berdampak terhadap peningkatan hasil belajar siswa.

\section{Ucapan Terimakasih}

Terimakasih kepada Tuhan Yang Maha Esa yang telah menyertai penelitian ini dari awal sampai selesai dengan baik. Mengucapkan terimakasih kepada kedua orang tua yang telah memberikan dukungan baik material maupun doa. Terimakasih kepada dosen pembimbing Dr. Henny Dewi Koeswanti, M.Pd. yang telah memberikan bimbingan sehingga dapat terselesaikan dengan baik, Agustina Tyas Asri Hardini, S.Pd. M.Pd. sebagai validator materi, Yohana Setiawan, M.Pd. sebagai validator media, Ibu Firosalia Kristin, M.Pd. sebagai validator desan media. Serta kepada semua pihak yang telah membantu.

\section{Daftar Pustaka}

Aqib, Z. (2011). Penelitian Tindakan Kelas Untuk Guru, SD, SLB, dan TK. Yrama Widya.

Awan, O., Dey, C., Salts, H., Brian, J., Fotos, J., Royston, E., Braileanu, M., Ghobadi, E., Powell, J., Chung, C., \& Auffermann, W. (2019). Making Learning Fun: Gaming in Radiology Education. Academic Radiology, 26(8), 1127-1136. https://doi.org/10.1016/j.acra.2019.02.020

Azhar, A. (2011). Media Pembelajaran. Raja Grafindo Persada.

Ibrahim, M., Antonenko, P. D., Greenwood, C. M., \& Wheeler, D. (2012). Effects of segmenting, signalling, and weeding on learning from educational video. Learning, $\begin{array}{llll}\text { Media } \quad \text { Technology, 37(3), 220-235. } & \end{array}$ https://doi.org/10.1080/17439884.2011.585993

Mawardi, M. (2014). Model Desain Pembelajaran Konsep Dasar PKn Berbasis Belajar Mandiri Menggunakan Moodle. Widya Sari Press.

Nisrinafatin. (2020). Pengaruh Game Online Terhadap Motivasi Belajar Siswa. Jurnal Edukasi Nonformal, 115-122.

Novianto, Y., Informatika, T., Dinamika Bangsa, S., JI Jend Sudirman, J., \& -Jambi, T. (2015). Perancangan Game Edukasi Pengenalan Binatang Dan Habitatnya Berbasis Android (Studi Kasus: Tk Ar Ridho Kel.Eka Jaya Jambi). Jurnal IImiah Media Processor, 10(1), 436-443.

Perini, S., Luglietti, R., Margoudi, M., Oliveira, M., \& Taisch, M. (2018). Learning and motivational effects of digital game-based learning (DGBL) for manufacturing education -The Life Cycle Assessment (LCA) game. Computers in Industry, 102, 40-49. https://doi.org/10.1016/j.compind.2018.08.005

Prayudi, K. A. W., Arthana, I. K. R., \& Wirawan, I. M. A. (2015). Pengembangan Game Labrin Matematika Tingkat SD. Kumpulan Artikel Mahasiswa Pendidikan Teknik Informatika, 4(5), 414-421. https://doi.org/http://dx.doi.org/10.23887

Rozie, F. (2018). Persepsi Guru Sekolah Dasar Tentang Penggunaan Media Pembelajaran Sebagai Alat Bantu Pencapaian Tujuan Pembelajaran. Widyagogik, 5(2), 1-12. https://doi.org/https://doi.org/10.21107/widyagogik.v5i2.3863

Rusman. (2017). Belajar \& Pembelajaran Berorientasi Standar Proses Pendidikan. Prenadamedia Group. 
Sandrone, S., \& Carlson, C. (2021). Brain Disorders Gamification and game-based education in neurology and neuroscience: Applications, challenges, and

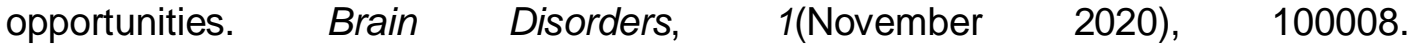
https://doi.org/10.1016/j.dscb.2021.100008

Smaldino, S. E., Lowther, D. L., \& Russell, J. D. (2008). Instructional technology \& media for learning: Teknologi pembelajaran dan media untuk belajar. (Terjemahkan Arif Rahman). Kencana.

Sukmadinata. (2016). Metode Penelitian Pendidikan. Remaja Rosdakarya.

Sundara, K., Hafsah, H., \& Nasar, M. A. (2020). Pengaruh Negatif Game Online Terhadap Motivasi Belajar Siswa di SMKN 1 Narmada. Civicus: Pendidikan-PenelitianPengabdian Pendidikan Pancasila Dan Kewarganegaraan, 8(2), 84. https://doi.org/10.31764/civicus.v8i2.2885 